\title{
TORTOISES AND HARES: DISSOLUTION, EROSION AND ISOSTASY IN LANDSCAPE EVOLUTION
}

\author{
MICHAEL J. SIMMS* \\ Department of Geology, Museums and Galleries of Northern Ireland, Ulster Museum, Botanic Gardens, Belfast, BT9 5AB, UK
}

Received 6 December 2002; Revised 18 July 2003; Accepted 29 July 2003

\begin{abstract}
Denudation mechanisms differ fundamentally between limestone and silicate rock types, which are subject to very different rate thresholds and enhancers/inhibitors. Silicates are removed largely by erosion, the mechanical entrainment and transport of particles. This is a relatively high energy, and highly episodic, process which occurs only when a minimum threshold flow velocity is exceeded; it is inhibited by vegetation cover and favoured by strongly seasonal runoff. Limestone is removed largely by chemical dissolution at a rate directly proportional to runoff. Dissolution is a relatively low energy process that can occur at any flow velocity or in static water; in general it is enhanced by vegetation cover and non-seasonality of runoff. These contrasting factors in the denudation of silicates versus limestone can produce strikingly uneven rates of surface lowering across a landscape, sometimes akin to the well known 'tortoise and hare race', where the slow and steady denudation of limestones may in the long term exceed the sometimes rapid, but often localized and episodic, erosion of silicates. Prolonged exposure of limestone to a humid temperate climate in a tectonically stable environment produces lowrelief corrosion plains in which limestone uplands are anomalous and, in most instances, due to recent unroofing from beneath a siliciclastic cover. In a highly seasonal or semi-arid climate almost the exact inverse may develop, with 'flashy' runoff and sparse vegetation favouring erosion rather than dissolution. Even under a constant humid climate progressive unroofing of a thick limestone unit within folded siliciclastics may lead to a topographic inversion over time, with the limestone outcrop always forming a topographic low flanked by siliciclastic uplands. Valleys will be initiated on anticlinal crests, where the limestone is first unroofed, but progressive lowering of the limestone causes these valleys to migrate to their final position in the synclinal troughs. In humid climates isostatic compensation in response to slow, but continuous, denudation of extensive limestone outcrops may be a significant factor in the development of relief on adjacent, more slowly eroding, silicate outcrops. Copyright (C) 2004 John Wiley \& Sons, Ltd.
\end{abstract}

KEY WORDS: limestone; silicates; denudation; climate; isostasy; topographic inversion; Ireland

\section{INTRODUCTION}

There has long been a division among geomorphologists between those studying landscape development associated with limestone dissolution and those investigating denudation, by weathering and erosion, on silicate rocks that are effectively insoluble. Jennings (1967, p. 256) commented that 'karst has long constituted an almost autonomous field within the scientific study of scenery' while Williams (1978, p. 260) noted 'the usual exclusion of karst from discussions of fluvial geomorphology and morphometry'. Consequently the contrasting effects of different denudational processes across major lithological boundaries appear to have been neglected. This is a minor issue in areas underlain by relatively homogeneous geology, but fluctuating depositional environments and/or the subsequent deformation of originally flat-bedded successions has led to the common juxtaposition of major limestone units against silicate rock types. In such cases understanding how the landscape evolves can be achieved only through a holistic approach where the different denudational mechanisms involved are considered together.

Even a cursory consideration of denudation mechanisms for limestone and silicate rocks reveals fundamental differences between them in factors such as rates, thresholds and enhancers/inhibitors. All of the data to evaluate these factors for the contrasting rock types are widely available in many standard textbooks (Ford and Williams,

\footnotetext{
* Correspondence to: M. J. Simms, Department of Geology, Museums and Galleries of Northern Ireland, Ulster Museum, Botanic Gardens, Belfast, BT9 5AB, UK. E-mail: michael.simms.um@nics.gov.uk
} 
1989; White, 1988; Boggs, 1987; Summerfield, 1991) yet no direct quantitative comparisons appear to have been made. Consequently the issue of how geologically heterogeneous (siliciclastic and limestone) landscapes respond to denudation, and how such landscapes evolve, is seldom addressed.

\section{DENUDATION MECHANISMS: PARTICLE ENTRAINMENT VERSUS DISSOLUTION}

Denudation of effectively insoluble silicate rocks occurs largely through mechanical erosion, by the physical removal of rock particles. Although dissolution often contributes to weathering and the disaggregation of rock in situ, the actual removal or erosion of the particles requires their entrainment and transport. Without erosion this weathered material remains in situ, as saprolite, sometimes attaining thicknesses of tens of metres and persisting for many thousands of years (e.g. Oguchi et al., 1999). Although glaciation is an important erosional mechanism in polar regions, and has been more widely during the glacial advances of the Pleistocene, most erosion is effected by liquid water. However, on largely insoluble rocks mere contact between water and rock is not sufficient to effect erosion. Hjulström (1935), and others subsequently (e.g. Sundborg, 1956; Novak, 1973), showed that particle entrainment requires water flow to exceed a threshold velocity below which particles remain stationary. For particles greater than about $1 \mathrm{~mm}$ diameter this threshold velocity increases with particle size but smaller particles do not conform to a simple extrapolation of this relationship. Threshold velocity reaches a minimum for particles between 0.1 and $1 \mathrm{~mm}$ diameter but shows a dramatic inverse relationship at smaller diameters (Figure 1), a consequence of molecular cohesive forces becoming increasingly significant with decreasing particle size. The somewhat counter-intuitive effect of this markedly non-linear relationship is that entrainment velocity for particles of $0.003 \mathrm{~mm}$ diameter is the same as that for particles of $10 \mathrm{~mm}$ diameter; a diameter ratio of 1:3300 and a volume, and mass, ratio of 1:37 000! High velocity floods can entrain and transport both fine and coarse material (Craig, 1987), in turn causing further erosion and entrainment. In contrast, slow flow may cause little or no erosion.

Various factors may contribute to particle entrainment and, once entrained, transport velocities are lower, especially for particles smaller than $1 \mathrm{~mm}$ diameter (Figure 1). Ahnert (1970) noted a direct correlation between local relief and mean denudation rate, a consequence of the effect of slope, and gravity, on water flow and particle inertia. Extrinsic entrainment mechanisms include impacts from raindrops, from other particles, or through biological activity (e.g. Scoging, 1989). Hence entrainment may occur at flow velocities lower than predicted solely from the Hjulström Curve. Other factors may raise entrainment thresholds; the most significant

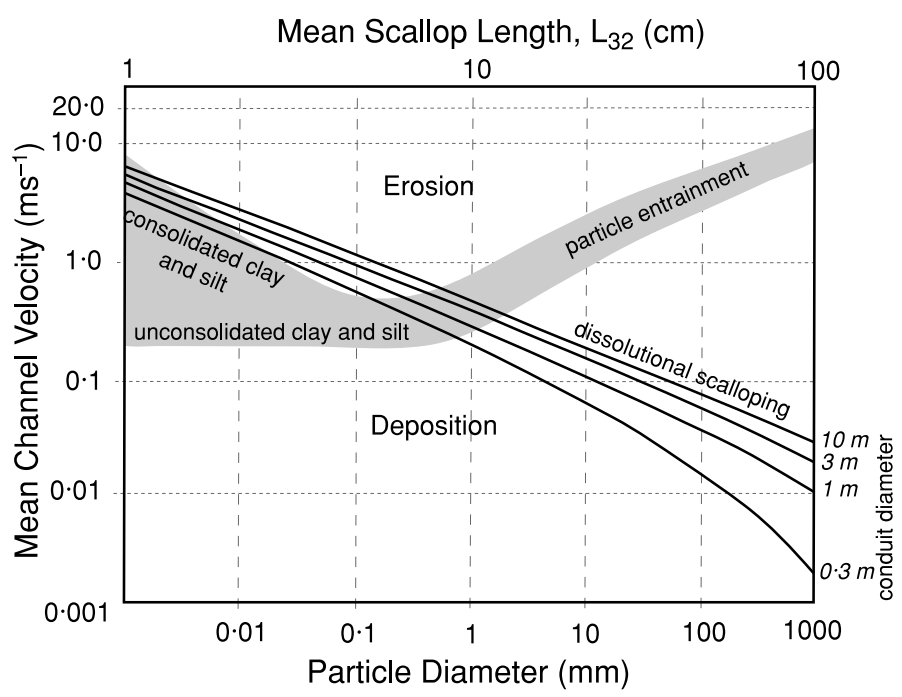

Figure 1. Relationship between water flow velocity, entrainment of particles, and dissolutional scalloping. Particle entrainment data after Sundborg (1956), based on a water depth of $1 \mathrm{~m}$. Scallop data from White (1988) 
is vegetation, which is discussed in a later section. Nonetheless, despite these various caveats, a critical aspect of erosion is that a threshold flow velocity exists below which erosion does not occur.

In contrast, limestone denudation occurs predominantly by dissolution. Mechanical erosion of limestone may also occur but is subject to the same constraints as erosion of silicates. Cited karst denudation rates often fail to take erosion into account and hence, if estimated from solute loads, may be lower than the actual denudation rate. Unlike erosion, there is no absolute limiting threshold for dissolution (Ford, 1980; Ford and Drake, 1982) - even static water can effect dissolution - although there is a rate threshold at the laminar/turbulent flow transition whereupon dissolution rates increase approximately five-fold (Ford and Williams, 1989). It is possible to demonstrate graphically, and from simple field observations, that limestone dissolution continues at flow velocities far below the threshold for erosion of even poorly consolidated sediment.

(i) Graphical method. Turbulent channelized flow of water across limestone, both in caves and on the surface, commonly dissolves concave hollows, called scallops (Ford and Williams, 1989), the dimensions of which are a function of flow velocity. Larger scallops indicate slower flow than do smaller ones, as summarized graphically by White (1988). Superimposing White's (1988) scallop graph onto the Hjulström Curve (Figure 1) reveals that scallop formation, and therefore dissolution, continues even at flow velocities two orders of magnitude slower than the minimum threshold velocity for entrainment of any particle.

(ii) Field observations. The same principle can also be demonstrated by paragenetic cave passages. Paragenesis occurs in phreatic (completely flooded) conduits where prevailing flow rates are too slow to entrain or transport particles. Hence sediment, often very fine grained (silt or clay), is deposited on the passage floor where it may protect the limestone beneath from further dissolution, which instead is confined entirely or largely to the limestone exposed above the sediment fill (Lauritzen and Lundberg, 2000). Over time a tall canyon-like passage forms by upward migration of the roof (Figure 2) with water flow confined to a relatively small space above a thick sediment fill. This simultaneous dissolution of the roof and deposition of fine sediment on the floor demonstrates, in microcosm, the profound contrast between velocity-thresholdconstrained particle movement and velocity-threshold-free limestone dissolution.

These various contrasting factors imply that denudation tends to be more continuous over time on limestone than on other rocks. Denudation of limestone occurs whenever undersaturated water is in contact with limestone, irrespective of flow velocity, whereas denudation of silicate rock types requires high flow velocities for erosion to occur. Walling and Webb (1986) found that for the River Creedy catchment (including both siliciclastics

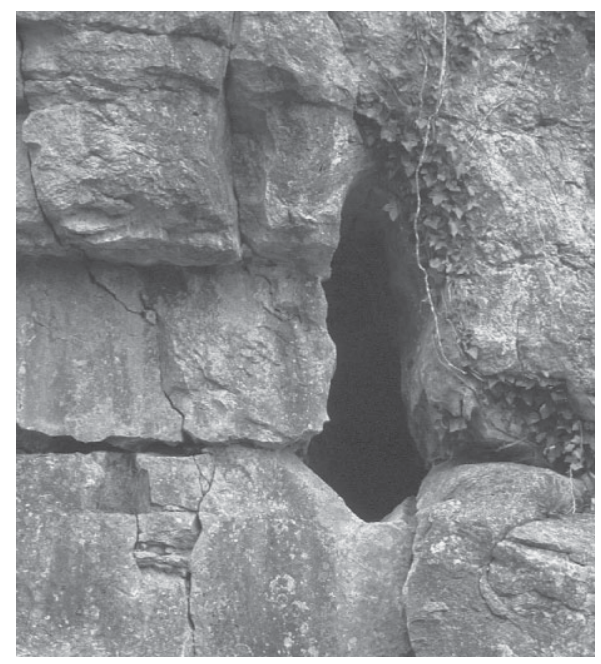

Figure 2. Paragenetic canyon at Oughtdarra, the Burren, Ireland. Cave development was initiated on the conspicuous bedding plane, with subsequent sediment deposition confining dissolution to the roof, causing it to migrate upwards. The sediments in this example have since been eroded out. Height of passage $c .2 \mathrm{~m}$. 
and limestone) in Devon, England, 90 per cent of the dissolved load was transported in 204 days per year (56 per cent of the time) while the equivalent proportion of the suspended load was transported in only 22 days per year (6 per cent of the time) corresponding to times of high flow. Similarly, Knighton (1973) found that for the River Bollin-Dean in Cheshire, England, nearly 80 per cent of bank erosion occurred in less than 5 per cent of the time.

The same factors also imply that denudation of limestone will be more evenly distributed across an outcrop than is the erosion of silicates; dissolution of limestone will occur across the entire outcrop exposed to rainfall whereas erosion necessarily is confined to narrow zones where flow rates are high.

However, even the highest limestone dissolution rates seldom exceed a few millimetres per year (Trudgill, 1976; Viles and Trudgill, 1984), seemingly insignificant when compared with the scale of mechanical erosion which sometimes may amount to several metres for a single event. Nonetheless, in certain climates the slow but continuous dissolution of limestone may, in the long term, exceed the sum of the sporadic larger-scale erosional events responsible for denudation of silicate rock types. In effect a kind of denudational 'tortoise and hare' race is operating, eventually to be won by the 'tortoise' of dissolution.

\section{VEGETATION COVER: ENHANCER VERSUS INHIBITOR}

Vegetation, from algal films to climax forest, profoundly influences erosion rates in several different ways. Soil or regolith is bound together by plant roots or fungal hyphae; Smith (1973) found that sediment cohesiveness of river channel banks increased with root volume of grass and shrubs. Vegetation also commonly forms a physical barrier between flowing water and the rock or regolith beneath, and it also absorbs the energy of impacting raindrops (Brandt and Thornes, 1987). Brandt and Thornes (1987) summarized the energetics of hillslope runoff, citing Darcy-Weisbach resistance factors of 24-500 for bare surfaces but 1000-40000 for vegetated surfaces, indicating the enormous energy-absorbing capacity of vegetation cover. They concluded that it is ground and near-ground cover that provides the greatest capacity for energy absorption, and hence inhibition of erosion. Similarly, Emmett (1978) cited a ten-fold increase in runoff energy required to overcome vegetation cover, and this only to effect water flow without any sediment transport. Even in upland fluvial channels, where erosion is most active, Eaton et al. (2003) concluded that the presence of coarse bedload and porous regolith mantling the slopes reduced the effectiveness of frequent, low-magnitude storms for mobilizing sediment. All of these various factors inhibit particle entrainment, raising the threshold velocity significantly above that predicted from particle size alone.

The effects on erosion rates of deforestation by one mechanism or another (e.g. Moody and Martin, 2001), or of cultivation (Golubev, 1982), are well known. Morisawa (1985) cited various studies showing that a change from forestry to agricultural use could increase sediment yields by a factor of as much as twenty. However, it is natural variations in vegetation cover, due largely to climate, that are of greater significance for long-term landscape change. In arid environments there is little vegetation but also little rain; hence exposure of bare rock and soil may be extensive but significant erosional events are infrequent. In contrast, regions with a humid climate but a low degree of seasonality (rainfall evenly spread through the year) will support a rich vegetation cover which is effective at protecting soil and regolith from erosion. Hence rainfall events with sufficient erosional power to overcome this vegetation cover are relatively infrequent here too. Between the two extremes are regions where rainfall is too infrequent or too seasonal for a dense vegetation cover to develop, or where vegetation periodically is destroyed by fire or drought to expose the soil and rock beneath (Meyer et al., 1992; Moody and Martin, 2001). In such environments runoff events may be sufficiently frequent and intense to cause significant erosion. Indeed, commonly there is an inverse relationship between annual runoff and runoff variability (Schmidt, 1985), i.e. arid climates are often characterized by occasional intense rainfall events, and a direct relationship exists between runoff variability and sediment yield (Wolman and Miller, 1960).

Langbein and Schumm (1958) quantified these observations in terms of sediment yield (tons $\mathrm{km}^{-2}$ ) for different climates (Figure 3), observing a steep rise in sediment yield from a minimum in areas of extreme aridity through to a maximum, of 300-350 ton $\mathrm{km}^{-2} \mathrm{a}^{-1}$, where effective annual rainfall (= runoff) is about $250-350 \mathrm{~mm}$, which corresponds to semi-arid grassland. Their data suggested a rapid decline beyond this, levelling out at about 100 ton $\mathrm{km}^{-2} \mathrm{a}^{-1}$ for annual runoff of $>1500 \mathrm{~mm}$. Similar studies (e.g. Douglas, 1967; Wilson, 1973; Ohmori, 


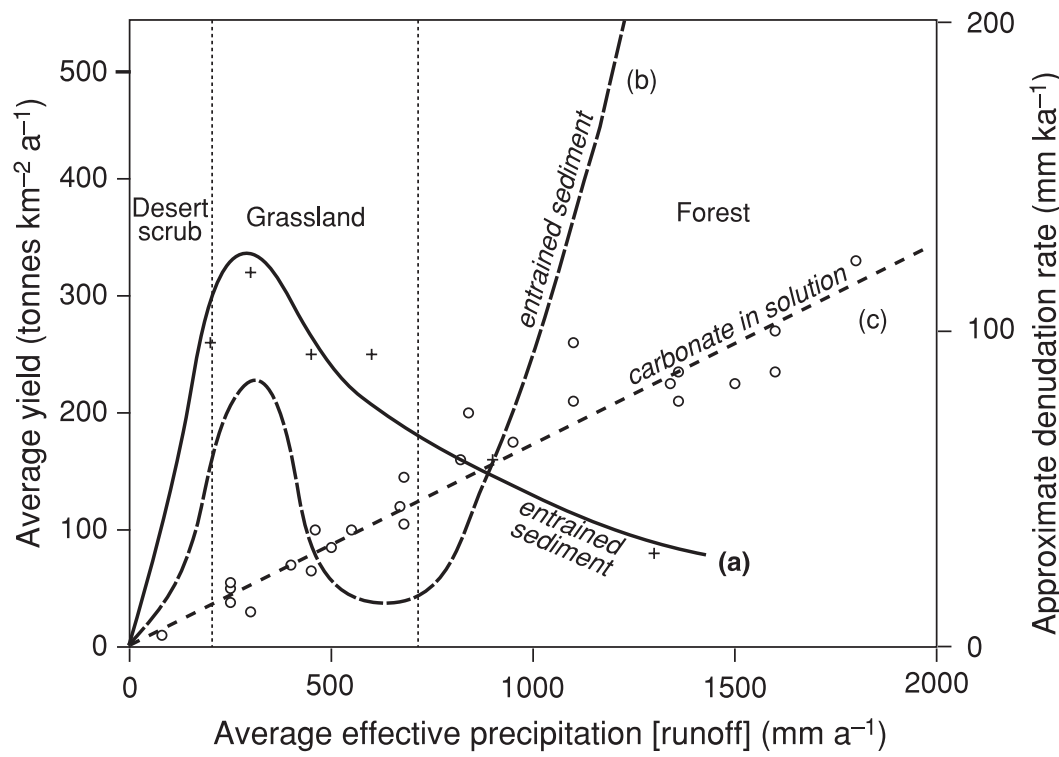

Figure 3. Relationship between effective precipitation (annual runoff), annual sediment yield for silicate outcrops, and annual dissolved carbonate load from soil-covered karst regions. Sediment yield and dissolution data after (a) Langbein and Schumm (1958), (b) Ohmori (1983) and (c) Atkinson and Smith (1976)

1983), although differing significantly in detail, have confirmed the existence of this initial peak and trough although some suggest that erosion rates may rise again in areas of very high precipitation or runoff. At the other end of the scale, Schmidt (1985) noted that trends in his data indicated that the peak of suspended sediment yield appeared to approximate closely to the point of zero runoff. Wilson (1973) highlighted the importance of precipitation seasonality; annual runoff of $1500 \mathrm{~mm}$ spread evenly through the year, as is typical for many western European regions, is far less effective in terms of erosion and sediment yield than rainfall concentrated into a short rainy season or brief high-intensity storms. He suggested the Langbein-Schumm curve was approximately correct for continental climates (warm moist summers and cool-moist/cold-dry winters), but commented that in general these curves have little quantitative value. Furthermore, although it is possible to calculate an average denudation rate from the sediment yield figures, it must be remembered that, particularly in well vegetated areas, these figures actually derive from relatively narrow zones where erosion rates are high (fluvial channels) surrounded by much more extensive areas where erosion rates are very much lower. This highly localized nature of fluvial erosion is exemplified by a common and widespread feature of many fluvial systems - river terraces. On largely insoluble, silicate-dominated lithologies extensive areas of terrace gravels may experience negligible surface lowering over hundreds of thousands of years while, over the same period, the adjacent channel may be incised tens or even hundreds of metres (see examples in Bridgland, 1994).

The effects of vegetation on limestone dissolution provide a striking contrast to this. Although vegetation may form an effective barrier between fast-flowing water and bedrock, inhibiting erosion, it may be less effective at preventing the slow downward percolation of water through the soil cover, particularly in areas where precipitation significantly exceeds evapotranspiration (Trudgill et al., 1983). The abundance of speleothems (stalactites and stalagmites) of redeposited calcite in many cave passages at shallow depth beneath soil and vegetationcovered limestone outcrops testifies to the efficacy of percolating water in dissolving the limestone. Since dissolution is not dependent on fast flow rates it can occur across an entire limestone outcrop even beneath a soil cover, unlike erosion which is confined to narrow zones of high flow rates at the immediate surface. Furthermore, vegetation and soil organisms generate high soil-water $\mathrm{CO}_{2}$ concentrations which accelerate dissolution compared with bare rock surfaces (Crowther, 1979; Trudgill, 1976, 1977). A direct relationship exists, therefore, between carbonate dissolution and runoff (Atkinson and Smith, 1976; Lang, 1977). Comparing the dissolution data of Atkinson and Smith (1976) with published sediment yield curves (Figure 3) shows that under 
certain conditions long-term limestone dissolution rates may exceed long-term erosion rates. For the LangbeinSchumm curve this occurs where annual runoff exceeds about $1000 \mathrm{~mm} \mathrm{a}^{-1}$.

In limestone terrains dissolution broadly equates with surface lowering, as exemplified by the pedestals commonly found beneath erratics on exposed areas of limestone pavement (Ford and Drake, 1982; Jennings, 1985). Gunn (1986) estimated that 50-85 per cent of dissolution in a karst drainage basin is concentrated in the epikarstic, or subcutaneous, zone and contributes directly to surface lowering. Indeed, the enhanced permeability of limestone near the surface is a direct consequence of dissolution here. Similarly, Atkinson and Smith (1976) cited various published data in further support of this while their own data, from the Mendip Hills, England, indicated that almost 70 per cent of limestone dissolution occurred within about $10 \mathrm{~m}$ of the surface. It is further supported by the process-response models of Carson and Kirkby (1972) which suggest that in temperate climates limestone outcrops experience slope decline whereas other rock types develop lower-slope concavities and parallel slope retreat. Nonetheless, dissolution rates may vary across an outcrop and, under certain conditions and at certain scales, this may produce significant topographic relief. This commonly develops as a consequence of focusing of dissolution, typically in areas of greater fracture intensity allowing enhanced downward or lateral vadose flow, and hence perhaps turbulent rather than predominantly laminar flow, or as a result of allogenic surface drainage onto the limestone. This spatial variation in dissolution rates manifests itself largely at the surface, as dolines or closed depressions. Although cave passages represent an obvious focus of karst drainage, they account for only a tiny percentage (c. 1.5 per cent) of total dissolution in karst areas (Atkinson and Smith, 1976). Cone and tower karst represent extreme examples of dissolutional focusing but appear confined to tectonically active regions where uplift rates are faster than the average surface lowering rate attributable to dissolution, but slower than the enhanced dissolution rates that prevail at points of focused drainage (Smart et al., 1986; Sweeting, 1990). Consequently the dolines are deepened as base level falls leaving residual hills between them. However, surface lowering of the tower or cone summits does continue and, if uplift ceases and base level falls more slowly than the surface lowering rate, a low relief corrosion plain will develop as both doline floors and hill summits approach a common base level (Smart et al., 1986).

Despite these conspicuous exceptions, in most instances surface lowering of limestone continues fairly evenly across the outcrop both on exposed surfaces and beneath soil and vegetation. In contrast mechanical erosion tends to be focused on linear surface watercourses (Stark and Stark, 2001) and may be minimal on interfluves. But these contrasting processes, dissolution and erosion, are not mutually exclusive. Erosion of limestone may be significant where runoff is high, even if only sporadically, and has been a dominant factor in the excavation of many limestone gorges and dry valleys (Waltham et al., 1997). Solute loads for streams draining silicate outcrops may be considerable and comparable with figures for karst areas (Gunn, 1986), while weathering and dissolution of silicates also is higher beneath vegetation (Bouchard and Jolicoeur, 2000). However, unlike dissolution of limestones, a direct relationship between solute load and denudation of silicate outcrops cannot be assumed (Walling and Webb, 1986). Dissolution of limestone is said to be congruent, in that all components dissolve together. However, dissolution of silicates generally is incongruent, with only certain components dissolving and the remainder being retained in reordered solids. Hence ion removal, in solution, from silicate outcrops merely alters mineral composition and reduces rock strength (Oguchi et al., 1999) without there necessarily being a significant volume difference between weathered and unweathered rock. The weathered silicate material persists as saprolite, which may reach thicknesses of many tens of metres (see Leopold et al., 1964, p. 124, for examples) unless removed by erosion. Saprolites testify to prolonged weathering of silicates without significant removal of material or surface lowering. This contrasts strikingly with carbonates, where weathering may remove pure limestones entirely by solution.

\section{IMPLICATIONS FOR LANDSCAPE DEVELOPMENT}

Differences in denudation process may have little direct bearing on overall landscape development except where thick limestone beds lie within other rocks or vice-versa, particularly where the mechanical strengths of the limestone and contiguous rocks are broadly similar (Clayton and Shamoon, 1998) and the succession has been folded. Through the contrasting controls on, and effects of, erosion and dissolution, strikingly different topographies may develop in different climates or in response to changing outcrop patterns. 


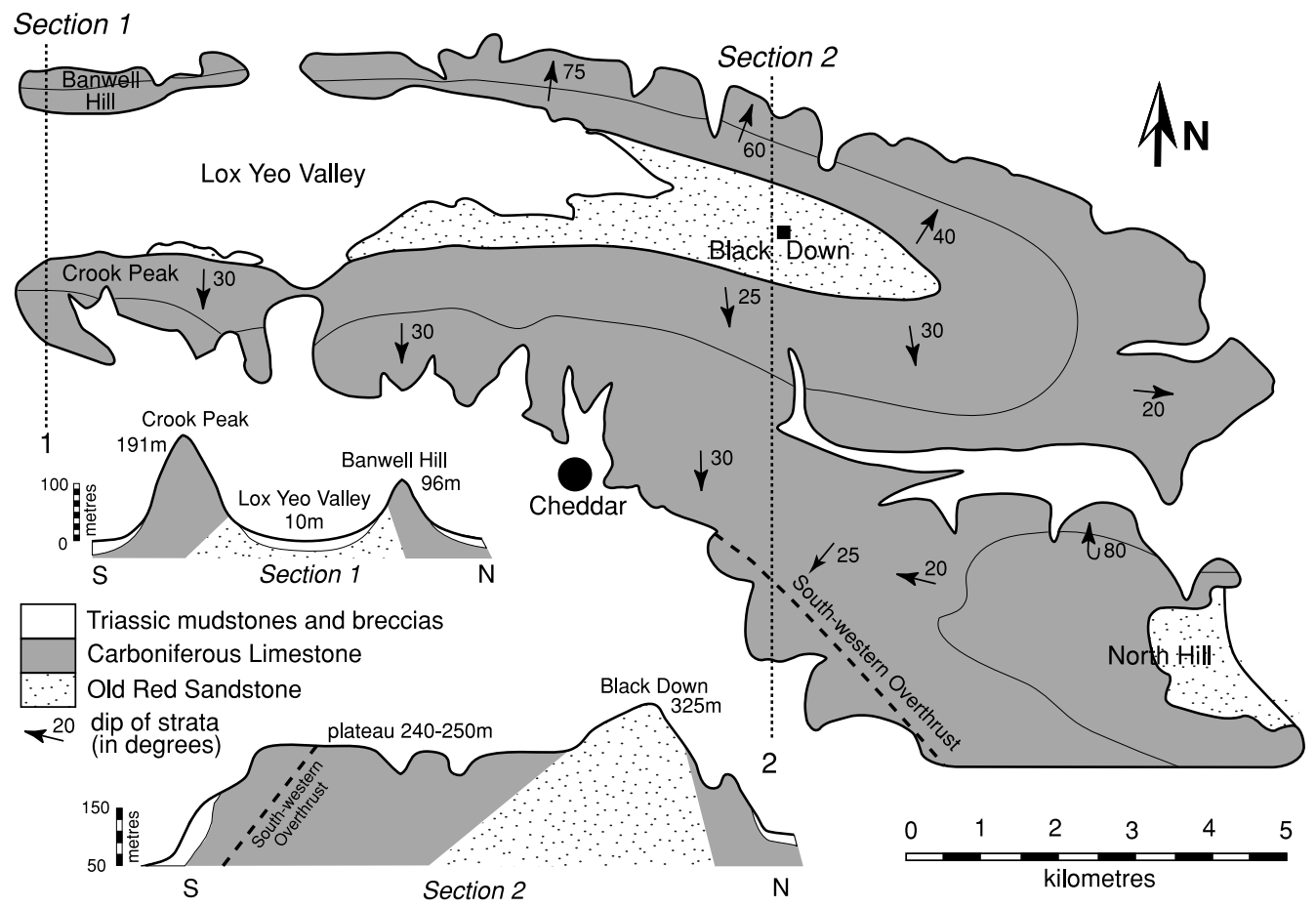

Figure 4. Outcrop map and cross-sections across the Black Down pericline, Mendip Hills, UK, showing denudation profiles generated by semi-arid conditions during the Permo-Triassis (Section 1) and humid conditions during the Pleistocene (Section 2)

\section{The effect of climate change}

In arid, sparsely vegetated regions silicate rocks commonly are more susceptible to arid-zone weathering processes (Goudie, 1989) than are indurated limestones and so are more readily eroded by occasional high runoff events. At the same time limestone outcrops commonly are mechanically resistant to these same high runoff events and experience only low dissolution rates. Consequently limestone in semi-arid regions may form strikeorientated ridges separated by mechanically weaker silicates, or limestones may experience slower scarp retreat rates than silicates (Oberlander, 1989). Limestone dissolution increases with rainfall, this often being accentuated by vegetation, yet vegetation simultaneously protects the silicate outcrops from erosion. Hence, in humid, non-seasonal climates, surface lowering rates for limestones may be greater than for silicates. Some aspects of this were alluded to by Hack (1960), who described examples from the humid temperate eastern United States where uplands correspond to siliciclastics and lowlands are underlain by limestones. Much of the Irish landscape is of this type, with limestone-floored lowlands now flanked by siliciclastic uplands regardless of their stratigraphic or structural (inlier or outlier; synclinal or anticlinal) relationships.

Nowhere are these climatically induced differences seen more clearly than in the Mendip Hills of southern England (Figure 4), a series of large periclines where $1000 \mathrm{~m}$ of Lower Carboniferous limestone lies between Devonian (Old Red Sandstone) and Upper Carboniferous ('Millstone Grit' and Coal Measures) siliciclastics (Simms, 1997). The region was exposed subaerially for tens of millions of years, throughout much of the PermoTriassic. The resultant palaeosurface was then buried beneath a cover of Triassic, Jurassic and later sediments, to be exhumed again only in the Pleistocene (Farrant and Smart, 1997). The first, Permo-Triassic, period of denudation was in a semi-arid climate and saw the Upper Carboniferous siliciclastics largely eroded from across the periclines. During this same period the exposed limestone experienced little dissolution and evidently was more resistant to erosion than the siliciclastics above and below. Only across the highest pericline was the limestone breached to expose the Old Red Sandstone beneath. Here, at the western end of the Black Down pericline, limestone ridges rise almost $200 \mathrm{~m}$ on either side of the Lox Yeo valley, which is now floored with 
Triassic mudstones resting unconformably on the Old Red Sandstone in the eroded core of the pericline (Figure 4, section 1). However, further east the sandstone core remained roofed by a continuous limestone cover throughout Permo-Triassic times which persisted, protected by Triassic and Jurassic sediments, right up until the Pleistocene. Now the Mesozoic cover has been stripped away exposing, to cold arid to temperate humid conditions, the same Palaeozoic succession and outcrop pattern as was exposed during the Permo-Triassic. The profound differences in denudation style between the Permo-Triassic and Pleistocene climatic regimes are reflected in the topography now developed on these periclines. With greater rainfall in the Pleistocene, compared with that in the Permo-Triassic, limestone dissolution rates appear to be more rapid than erosion rates on the adjacent siliciclastics. The topographic contrast between siliciclastics and limestone that has developed during the Pleistocene at the eastern end of the Black Down pericline is as striking as that at its western end, but is virtually the inverse of it. The Old Red Sandstone pericline core here now rises to a summit some $75 \mathrm{~m}$ above a surrounding corrosion plateau, at about 240-250 m OD, which cuts across the dipping limestone outcrop (Figure 4, section 2). The limestone ridges towards the western end of the pericline will also have experienced significant denudation during the Pleistocene, while the Triassic valley fill has yet to be completely removed. This implies that the present topography of the Lox Yeo valley, striking though it is, is relatively subdued compared with the original Permo-Triassic relief in which the ridges would have been higher and the valley deeper.

\section{Changing outcrop pattern and landscape evolution}

Just as different climatic regimes can produce strikingly different topographies from the same outcrop pattern, so dramatic landscape changes can arise in response to changing outcrop patterns through surface lowering of a folded succession (thick limestone sandwiched by thick siliciclastics, or vice versa) under a constant climate (Figure 5). As already discussed, moderate to high, non-seasonal, rainfall may cause faster denudation of limestones than of associated siliciclastics. Hence valleys will develop on the anticlinal crests where limestone is first unroofed from beneath a siliciclastic cover (Figure 5, line 2). Continued surface lowering will cause these valleys to broaden at the expense of the flanking siliciclastic outliers occupying the synclines. Siliciclastics beneath the limestone also will be unroofed first along the anticlinal crests, creating more resistant inliers which divide the initial broad valley into two parallel limestone-floored valleys, each located on the fold flank. Continuing erosion of the siliciclastic outliers in the synclines (overlying the limestone) and lowering of the limestone flooring the valleys occurs in parallel with the continuing emergence of the siliciclastic inliers in the anticlines (underlying the limestone). These valleys, flanked by an emerging siliciclastic inlier on one side and a diminishing siliciclastic outlier on the other (Figure 5, line 3), become increasingly asymmetrical as the valley floor shifts down-dip through surface lowering of the limestone outcrop. Eventually the last remnant of the siliciclastic

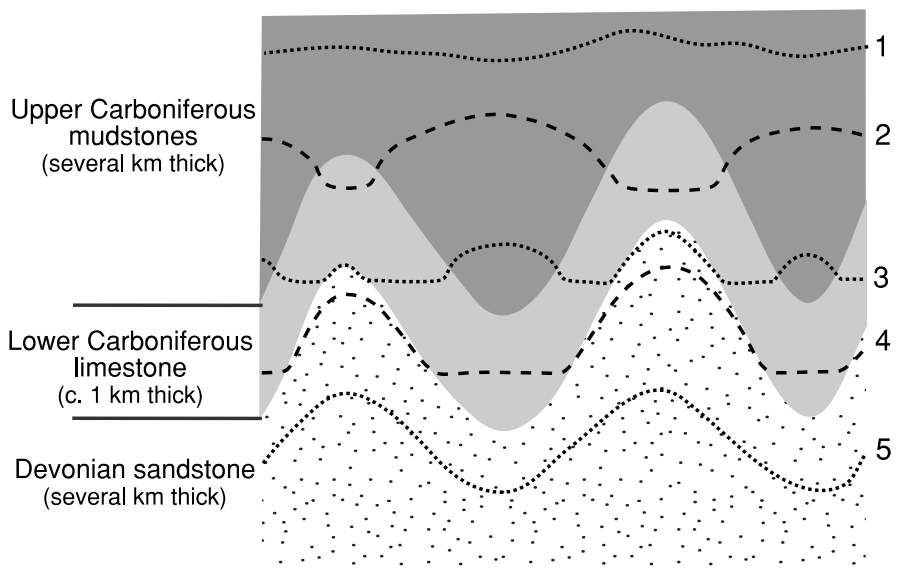

Figure 5. Hypothetical sequence of landscape development during progressive denudation of a folded silicate and limestone succession in a non-seasonal humid climate (based on southwest Ireland). The dashed lines (1-5) represent successive land surfaces which develop in response to the changing outcrop pattern during surface lowering 
outlier occupying the syncline is removed entirely by erosion, creating a single valley occupying the limestonefloored syncline (Figure 5, line 4). Ultimately even this limestone remnant may be removed (Figure 5, line 5). Examples of all of these stages of landscape evolution are present in southwest Ireland, particularly in and around what is commonly known as the 'ridge-and-valley province' (Herries Davies and Stephens, 1978). Evidence from dated cave fills indicates that in this area even some of the advanced stages had been reached by the mid-Tertiary (Simms and Boulter, 2000) yet any attempt to reconstruct former drainage patterns must necessarily consider the earlier stages in this sequence.

The overall implications for landscape development are profound since such a sequence involves a dramatic topographic inversion, with valleys migrating from the anticlinal axes (Figure 5, line 2) to synclinal axes (Figure 5, line 4) via a stage in which the number of strike-orientated valleys may double through the emergence of new siliciclastic inliers along the anticlinal crests and the persistance of siliciclastic outliers in the synclinal troughs (Figure 5, line 3). Similarly, unroofing of domes may lead to switching between convergent and divergent drainage patterns.

\section{DENUDATION AND ISOSTASY}

Creation of a landscape through denudation is not an entirely passive process but involves some interaction with isostatic properties of the crust. Crustal loading or unloading, through deposition or denudation, results in compensatory subsidence or uplift. Were it not for this process of isostatic compensation then long-exposed land surfaces eventually would be reduced to a classic peneplain, close to base level, cutting across diverse outcrop lithologies regardless of any lithological differences in denudation rate or mechanism (Phillips, 2002). Over small areas, of a few tens of square kilometres or less, isostatic uplift associated with denudation is unlikely to be significant. However, where prolonged denudation has occurred across a large area $\left(10^{3}-10^{4} \mathrm{~km}^{2}\right)$ isostatic uplift may have played a significant role in generating the topography now evident. The exact response of the land surface depends on the flexural rigidity of the lithosphere underlying it. If flexural rigidity is high then denudational unloading of one area, such as a river valley, will have a direct effect on its isostatic uplift and that of adjacent areas, such as mountain ranges, subject to lower denudation rates (Montgomery, 1994). Small and Anderson (1995) considered that lithospheric rigidity distributes the response to denudational unloading across a horizontal distance of 10 to $100 \mathrm{~km}$. Where denudation rates across an area vary according to lithology so the isostatic uplift will be a function of the average denudation rate (e.g. Farrant et al., 1995), although even the maximum isostatic compensation will be only about five-sixths $(0 \cdot 82)$ of the denudation due to the lower densities of surface rocks compared with those deeper in the crust (Gilchrist et al., 1994). If the more rapidly denuding lithology constitutes a major outcrop component of the area then isostatic unloading across its outcrop area will lead to relative uplift of more slowly denuding outcrops. This has obvious implications in temperate humid areas where extensive limestone outcrops are denuded more rapidly by dissolution than intervening silicate inliers and outliers are by erosion. If flexural rigidy is low then the topography arising from lithological, and resulting denudational, differences may be accentuated by differential rates of uplift across the area, or it may be accommodated by faulting. It is possible to model the interaction between denudation and isostatic uplift for a particular region and there are many instances where this has been done (e.g. Small and Anderson, 1995; Clayton and Shamoon, 1999).

Erosion of silicates invariably leads to the accumulation of sediments in depocentres elsewhere. Flexural isostasy associated with sediment loading in these basins may also contribute significantly to uplift of the adjacent denuded area (Pazzaglia and Gardiner, 1994; Farrant et al., 1995). However, if the main component of crustal unloading across a region is through denudation of limestone, removed in solution, then crustal loading of adjacent areas will be relatively low with a consequent reduction in the extent of the uplift associated with flexural isostasy.

It is not proposed to undertake a detailed analysis here of the overall effects on lithospheric flexure of crustal loading and unloading in a limestone-dominated region, but it is worth considering the role of isostasy in a temperate humid area which experiences more rapid denudation of limestones than of adjacent silicates. Such a situation is exemplified by the landscape of Ireland where extensive outcrops of limestone-dominated strata are interspersed with silicate outcrops. 


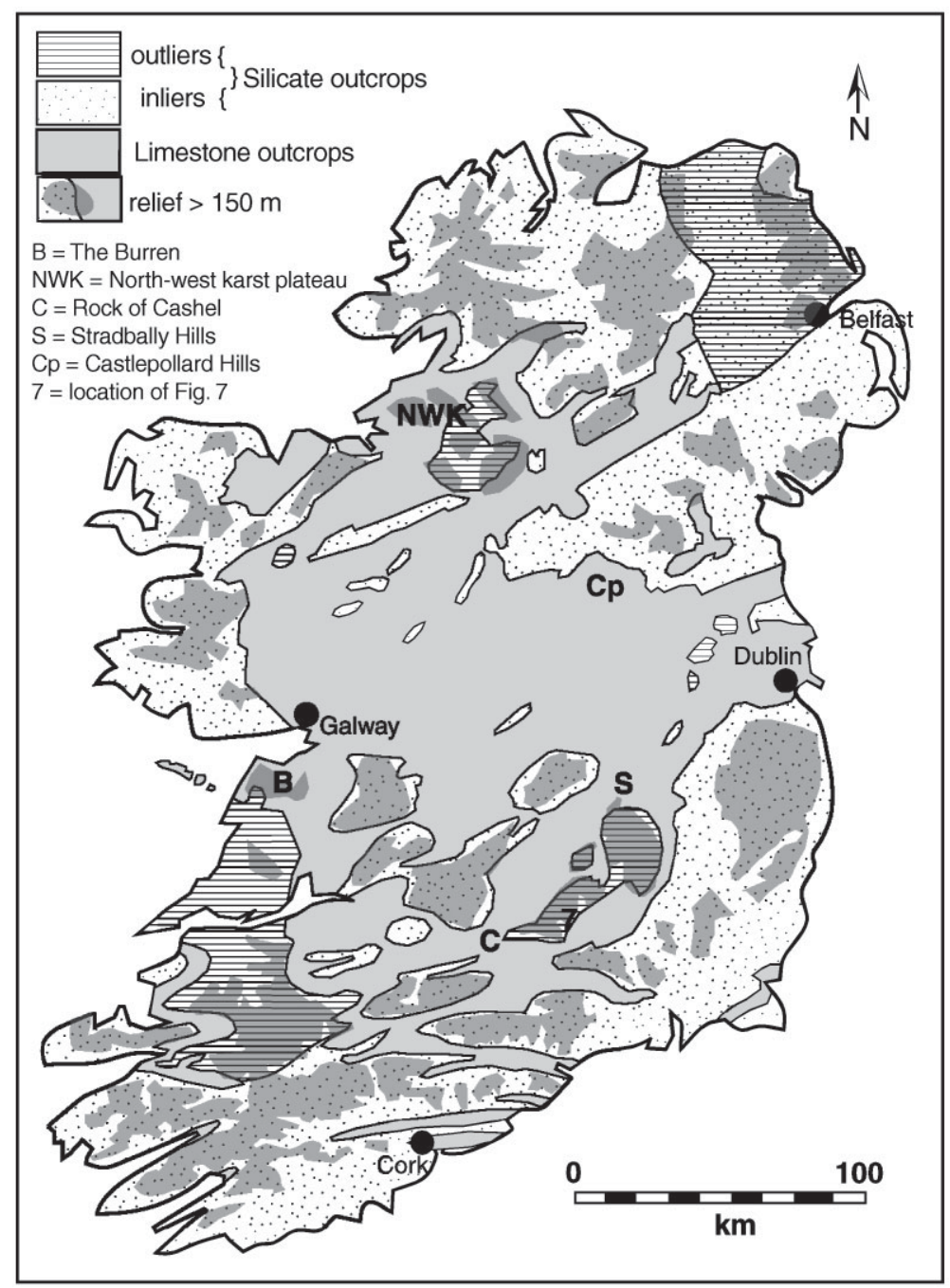

Figure 6. The location of significant upland areas (>150 m OD) in relation to lithology (silicates versus limestone) in the Irish landscape. Note that despite the extensive outcrop of limestone, only two relatively small areas (the Burren and the northwest karst plateau) exceed $150 \mathrm{~m}$ in altitude

\section{THE IRISH LANDSCAPE: AN EXAMPLE OF THE RELATIVE ROLES OF DISSOLUTION, EROSION AND ISOSTASY}

\section{Dissolution and erosion}

The relationship between topography and lithology (silicicates versus limestone) in the southern two-thirds of Ireland conforms closely to what might be expected from the 'tortoise and hare' model of denudation in nonseasonal humid climates. Limestone-dominated lithologies, mostly Dinantian (Early Carboniferous) in age, underlie more than a third of the total land surface area of southern Ireland and, with notably few exceptions, now form lowlands seldom rising above $60 \mathrm{~m}$ OD (Figure 6). Adjacent outliers, of Silesian (Late Carboniferous) age, and inliers, of Devonian or Early Palaeozoic age, are overwhelmingly of siliciclastics or other silicate lithologies. With few exceptions these form relative uplands rising a few tens to several hundred metres above the adjacent limestone outcrop (Figure 7). Much of this topographic relief can be ascribed to faster rates of dissolutional denudation on limestone outcrops than of erosional denudation across silicate outcrops, with an 


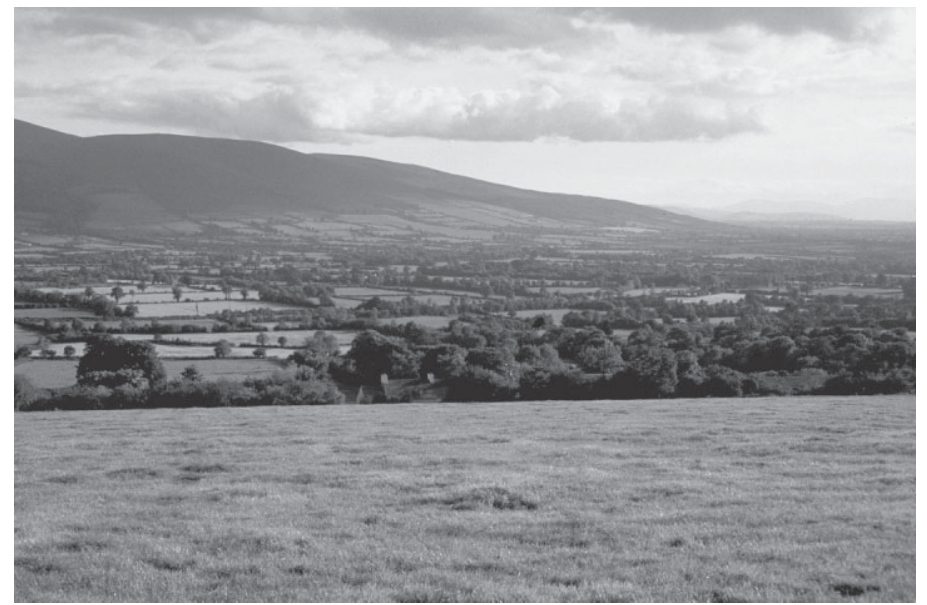

Figure 7. The Irish landscape epitomized. Looking southwards from the Silesian siliciclastic outlier of the Slieveardagh Hills, across the limestone lowlands around Mullinahone, to the Devonian siliciclastic inlier of Slievenamon, southeast Ireland

abundance of vegetation and relative rarity of high runoff events greatly enhancing dissolution while simultaneously inhibiting erosion. Although the resultant lowlands are located largely on Carboniferous limestones, a similar pattern is seen where much older limestone-dominated units, now metamorphosed to marble, occur in the extensive Dalradian (Precambrian) outcrops of Connemara to the northwest of Galway. Over much of their outcrop these marbles form elongate strips of low ground now occupied by ribbon lakes, giving rise to the name of the Lakes Marble Formation (Leake and Tanner, 1994), while adjacent quartzite outcrops typically rise hundreds of metres above them.

Evidence from across Ireland indicates that the landscape has been emergent throughout the Tertiary, a period of more than 60 million years (Naylor, 1998; Simms and Boulter, 2000). Surface lowering rates for exposed limestone in the Burren, Co. Clare, are estimated at around $40-50 \mathrm{~mm} \mathrm{ka}^{-1}$ (Drew, 2001). They may well be higher for sub-soil limestone outcrops across Ireland, and particularly adjacent to silicate outcrops where allogenic input may increase denudation rates significantly (cf. Pitty, 1968). In this context it is worth noting that some of the largest limestone-floored lakes in Ireland (e.g. loughs Corrib, Mask, Derg and Conn) are located adjacent to substantial allogenic catchments and have, at various times, been cited as examples of solution lakes (Williams, 1970). Bearing in mind quoted dissolution rates for Ireland, all exposed limestone would be denuded down to base level or stripped away altogether across anticlinal ridges within the first 20 million years or so following subaerial emergence of the Irish landmass in the early Tertiary. This would indeed appear to be the case across much of the Irish midlands, where the limestone forms a low plain punctuated by various upland massifs which have developed on anticlinal inliers of Devonian and older siliciclastics. In parts of the southwest of Ireland, in Cork, Kerry and Waterford, denudation has proceeded still further. Here the limestone outcrops are reduced to narrow low-lying strips along synclinal troughs flanked by anticlinal ridges of siliciclastics rising to several hundred metres above the valleys.

However, in parts of Ireland limestone hills or more extensive upland areas of limestone form a significant component of the landscape and would appear to be anomalous in light of the general conclusions on denudation rates discussed here. The two main limestone uplands are the Burren, in Co. Clare, and a more extensive upland region encompassing parts of Sligo, Leitrim, Fermanagh and Cavan; both extend across several hundred square kilometres and rise to altitudes of $>300 \mathrm{~m}$. Smaller limestone hills, typically rising no more than a few tens of metres above the surrounding lowlands and each covering no more than a few square kilometres, commonly occur in groups such as in the Castlepollard area of Co. Westmeath and the Stradbally Hills of Co. Laois. The Rock of Cashel in Co. Tipperary is a particularly well known example of one of these isolated limestone 'hums'. Average denudation rates for limestone in Ireland would reduce even the Burren to near base level within a few million years, as has happened on the Gort lowlands immediately to the east where the inclined limestone strata 
have been bevelled off to form a remarkably well developed corrosion plain (Williams, 1970). The presence of these uplands implies, therefore, that the limestone across them has been exposed for a relatively short time compared with adjacent lowlands (Williams, 1970; Herries Davies and Stephens, 1978).

However, by considering these limestone 'hums' and uplands in a wider context it becomes clear that in nearly all cases they owe their existence in the present landscape to a cover of siliciclastic sediments that was stripped from the limestone relatively recently. This is very evident in the Burren, where a shale cover is still present above the limestone down-dip to the south and persists in patches on the western Burren itself. Similarly, extensive remnants of a thick clastic cover, mainly of sandstones, are found across many parts of the SligoLeitrim-Fermanagh-Cavan limestone uplands. Of the minor limestone hills, those at Stradbally and the Rock of Cashel lie no more than a few kilometres from existing siliciclastic outliers on the limestone, namely the Castlecomer Hills to the south of Stradbally and the Slieveardagh Hills to the northeast of Cashel (Figure 6). The implication is that these minor limestone hills, or 'hums', were also protected until relatively recently by the dissected remnants of a once continuous siliciclastic cover. The scattered limestone hills of the Castlepollard region similarly occur only on the outcrop of the upper part of the Carboniferous Limestone succession; hence they too may represent 'ghosts' of an extensively dissected siliciclastic cover across the limestone.

Ireland has experienced repeated glaciations over at least the last few hundred thousand years (Coxon, 2001a) and their effects on landscape development should not be underestimated. Prolonged Tertiary weathering would have created thick, but mechanically weak, saprolites across many silicate outcrops. Glacial erosion, and fluvial erosion in poorly vegetated periglacial environments, were then able to strip this weathered material away with relative ease. The present limestone uplands may well have been unroofed in this manner, but other weatheringsusceptible silicate outcrops must also have experienced significant denudation at this time. Thus much of the extensive low ground across the Galway granite and the schists of southern Connemara probably represents an etch plain - a weathering front exhumed by glacial erosion (Coxon, 2001b) - and the pre-Pleistocene relief may well have been significantly greater than today. In contrast, dissolution of limestone, except where it has a high content of chert or other insolubles, produces little in the way of a weathering residue while its mechanical strength is not significantly reduced except perhaps in the epikarstic zone where there may have been significant removal of material. Consequently glacial erosion may have had a much lesser effect on the limestone outcrop than on the outcrops of many weathering-susceptible silicate rock types. Hence the topographic contrast between the limestone lowlands and the silicate uplands in parts of Ireland may have been even more pronounced prior to glaciation than it is today.

\section{Isostasy}

Much of Ireland's topographic relief could be ascribed simply to the contrasting denudation rates of dissolution and erosion in the Irish climate, but the unloading effects associated with this denudation should not be overlooked. Carboniferous Limestone underlies some 40 per cent of the surface of Ireland, an area of about $30000 \mathrm{~km}^{2}$ (Figure 6), and typically is several hundred metres to more than a kilometre thick (Sevastopulo and Wyse Jackson, 2001). Nonetheless, it has been removed entirely across large areas where Devonian and Lower Palaeozoic inliers have been unroofed, while elsewhere across its outcrop surface lowering has removed often hundreds of metres thickness of limestone. Just a one metre thickness of limestone removed across its entire outcrop area in Ireland amounts to an unloading of approximately 81 billion tonnes $\left(8 \cdot 1 \times 10^{10}\right.$ tonnes $)$. Hence isostatic compensation must be considered a significant factor in the development of a landscape from which hundreds of metres thickness of limestone may have been removed from across many thousands of square kilometres of the limestone outcrop during the Tertiary. Rates of post-glacial isostatic rebound across the British Isles (Shennan, 1989) suggest that isostatic compensation is rapid and largely equilibrated within $10 \mathrm{ka}$ of unloading. Limestone denudation across Ireland has probably been of the order of $50 \mathrm{~mm} \mathrm{ka}^{-1}$ through much of the Tertiary, several orders of magnitude slower than the most rapid rates of isostatic rebound. Hence uplift and denudation probably have maintained a dynamic equilibrium throughout this period. The average denudation rate across the whole area of Ireland considered here will be less than the limestone dissolution rate but more than the siliciclastic erosion rate. Hence isostatic uplift will be a function of the relative outcrop areas of limestone versus silicicates, and of any rock density differences. The precise details are not critical here; what is significant is that the average rate of isostatic uplift, due to the removal of limestone, will be greater than the 


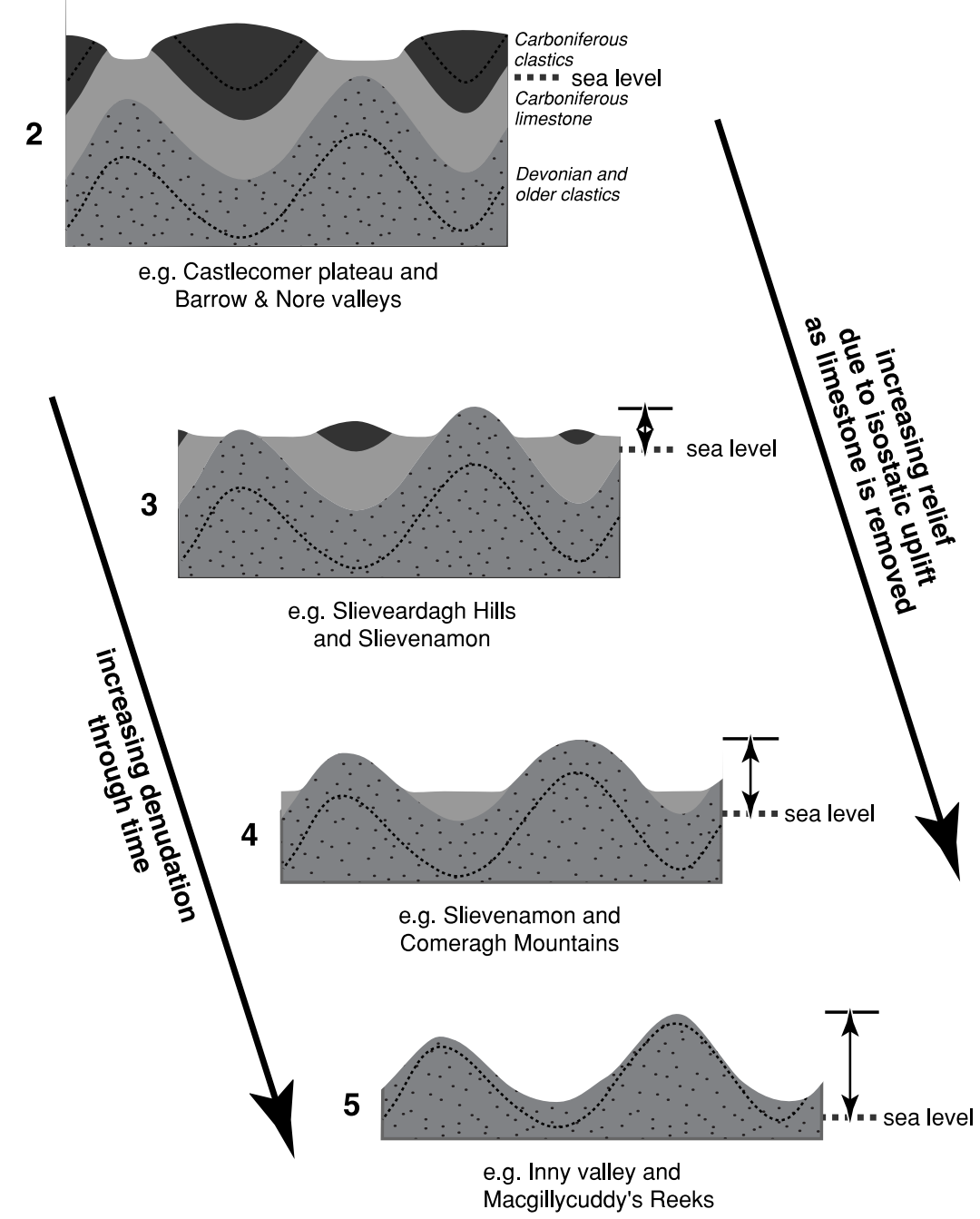

Figure 8. Diagrammatic summary of the effect of limestone denudation and isostasy in generating the relief of the landscape across south and southwest Ireland, with specific examples of each stage cited

denudation rate across the silicicate outcrops. It implies that while dissolution and isostatic uplift have together maintained much of the limestone outcrop at an altitude close to base-level, much of the present relief of the silicate outcrops, both for inliers and for outliers, has developed through long-term isostatic uplift at a rate that has exceeded silicate erosion rates (Figure 8). Denudational unloading, associated largely with limestone dissolution, has increased summit elevations on the silicate inliers and outliers in a manner analogous to that suggested by Small and Anderson (1995) for the Sierra Nevada of California. What we see now in the Irish landscape conforms broadly to the general conclusions of Phillips (2002), that differences in lithological resistance to denudation are manifested over time as topographic variations that are large compared to the initial relief. However, the present topography is very different from, in fact almost the inverse of, that which must have developed on the Carboniferous outcrop during the initial stages of unroofing of the limestone from beneath its siliciclastic cover. The topographic evolution of much of southern Ireland conforms closely to that summarized in Figures 5 and 8. As the siliciclastic Upper Carboniferous cover has been progressively stripped from the limestone beneath, first across the anticlines and eventually from the synclines, so the location of the valleys has shifted with the limestone outcrop from the anticline crests to the syncline troughs. The landscape seen in Figure 7 represents an intermediate stage, equivalent to Figure 5 line 3, where the syncline trough is still occupied 
by an outlier of siliciclastics and the valley is developed on limestone outcropping on the fold limb between the syncline trough to the north and the anticline crest to the south.

The potential contribution to isostatic uplift of crustal loading in offshore basins adjacent to the south and west of Ireland should also not be overlooked. The contribution to these basin fills from denudation of limestone would be limited although that from the overlying Silesian siliciclastics, now largely removed, could have been significant. Sediment volumes of between $10000 \mathrm{~km}^{3}$ and $20000 \mathrm{~km}^{3}$ are estimated to have been removed from Ireland during the Tertiary (Allen et al., 2002), a significant proportion of which must be represented by limestone. Since this would have been removed largely in solution it will have contributed little to offshore deposition, yet the total Tertiary sediment volume of the offshore basins to south and west of Ireland exceeds $100000 \mathrm{~km}^{3}$. Much of this may have originated from the northeast, during Palaeogene denudation of the uplifted Thulean Dome (Phillips, 2001) but, whatever its source, this basin fill must have exerted a significant influence on isostatic uplift in western Ireland.

\section{EXAMPLES FROM THE BRITISH LANDSCAPE: A PREPONDERANCE OF ANOMALIES?}

Britain and Ireland have broadly similar climates and hence a similar topography, of limestone lowlands and silicate uplands, might be anticipated in those parts of Britain with analogous outcrop patterns. The style of topography seen at the eastern end of the Blackdown pericline, in the Mendip Hills, where a siliciclastic inlier rises above a relatively flat corrosion surface developed on the inclined Carboniferous Limestone, has already been discussed and clearly is analogous with parts of the 'ridge-and-valley province' of southwest Ireland. This same pattern is encountered in other parts of Britain, notably in the Gower and in southwest Pembrokeshire in south Wales where similar corrosion surfaces cut across limestones which commonly dip at a steep angle. In contrast the upland limestone outcrop of the Yorkshire Dales indicates that across much of this region the limestone has not been exposed sufficiently long for dissolution to produce corrosion surfaces comparable with those just mentioned. It implies that unroofing of the limestone from beneath a Silesian (Upper Carboniferous) siliciclastic cover occurred here comparatively recently, probably in Pleistocene times, a possibility suggested by Sweeting (1974). Hence the Yorkshire Dales can be viewed as broadly analogous with the Burren.

In southern England there are extensive outcrops of post-Palaeozoic sediments significantly more weakly lithified than the Palaeozoic rocks that underlie much of Ireland. Although dominated by siliciclastics, this postPalaeozoic succession does include several significant limestone units. The most important occur in the Middle Jurassic, with the Inferior Oolite limestones more than $80 \mathrm{~m}$ thick in the Cotswold Hills, and in the Upper Cretaceous, where the Chalk reaches a maximum preserved thickness of $550 \mathrm{~m}$ in the Isle of Wight. Both are major scarp-forming units, in places rising to altitudes of more than $250 \mathrm{~m}$, yet denudation rates for these limestones, predicted from solute concentrations at springs (Goudie, 1990), indicate that such scarps could not persist for more than one or two million years unless the limestone was protected from dissolution by a silicate cap rock.

The apparent anomaly of how the Chalk can form such striking landscape features in the face of the predicted dissolution rates has been addressed by Jones $(1981,1999)$. Jones (1981) noted that in southern and southeast England the higher chalkland areas carry a discontinuous cover of superficial deposits, much of it derived from Tertiary siliciclastics which formerly overlay the Chalk. Indeed, the distribution of these superficial deposits suggests that in many places the present generalized topographic surface lies only a little below the sub-Tertiary unconformity surface, implying that a relatively short period has elapsed since the Tertiary cover was stripped from the Chalk in these areas. Rapid removal of the Tertiary siliciclastic cover was attributed to accentuated weathering and erosion under periglacial conditions during the Pleistocene and Jones (1981, p. 151) considered that 'prior to the first periglacial phase the chalklands must have carried a virtually continuous and thick superficial cover'. The poorly lithified nature of many post-Palaeozoic siliciclastics, compared with those from the Palaeozoic of Britain and Ireland, renders them particularly susceptible to periglacial effects. Summer thawing of the active permafrost layer in silt- and sand-dominated lithologies would produce a viscous slurry prone to gelifluction on even very gentle slopes (Ballantyne and Harris, 1994) or easily eroded by runoff, especially on the often poorly vegetated surfaces that prevail in such environments. This mechanism probably also contributed significantly to excavation of the clay vales located between the various scarps across much of 
southern England. Chalk itself is unusual, among limestones, in its behaviour under periglacial conditions. Williams (1980) found that saturated chalk begins to disintegrate even after just one freeze-thaw cycle, suggesting that during Pleistocene periglacial episodes measurable amounts of weathering could occur in a single winter. The resultant mixture of angular fragments and 'putty chalk' would then be highly susceptible to erosion and gelifluction. Rapid fluvial erosion of a seasonally thawed surface layer of this material during the colder periods of the Pleistocene may account for much of the smaller-scale topography on the chalklands, particularly the dry valleys which dissect both scarps and backslopes (Williams, 1980; Jones, 1981). In this respect the Chalk of southern England differs from other limestone outcrops in Britain and Ireland in that a significant component of its present topography is due to erosion during periglacial phases of the Pleistocene rather than to long-term dissolution. However, like other limestone uplands, the Chalk of southeast England owes its relief largely to relatively recent unroofing from beneath a siliciclastic cover.

The Jurassic limestone scarps and uplands of southern England and the East Midlands also appear to represent topographic anomalies, in defiance of predicted denudation rates (Goudie, 1990), but this issue has barely been addressed. Being at most only a few tens of metres thick, predicted dissolution rates indicate that few would survive even a million years and hence their present relief must be a transient role which they have assumed only recently. Significantly, however, these various scarp- and plateau-forming limestones are separated from each other by siliciclastic units, typically mudstone-dominated, of substantial thickness (Arkell, 1933). In the Lower Jurassic the Marlstone Rock Bed is seldom more than $10 \mathrm{~m}$ thick yet forms the Edge Hill scarp and a minor feature further south in the Cotswold Hills. It is separated from the substantially thicker, Middle Jurassic, Inferior Oolite Group by the Whitby Mudstone Formation, typically 50-100 m thick across the Cotswolds and East Midlands. In the East Midlands a significant, though extensively dissected, cover of Whitby Mudstone Formation still remains across much of the plateau between the Marlstone Rock Bed scarp and the Middle Jurassic outcrop to the east. This mudstone cover may have protected the present outcrop of the Marlstone Rock Bed from dissolution until late in the Pleistocene, in a manner analogous to the chalklands described by Jones (1981).

In the Middle Jurassic the Inferior Oolite and Great Oolite groups together constitute a thick (>100 m) limestone-dominated succession with only minor siliciclastic intercalations, which is succeeded by the Oxford Clay Group, a mudstone-dominated succession more than $100 \mathrm{~m}$ thick in Oxfordshire and the East Midlands. It might be conjectured that here too much of the present Middle Jurassic limestone outcrop was unroofed from beneath a cover of Oxford Clay only comparatively recently in a manner analogous to that described by Jones (1981) for the chalklands but, unlike the examples cited previously, there are very few remnants of this former cover on the Cotswold plateau and the edge of the Oxford Clay outcrop now typically lies $>15 \mathrm{~km}$ downdip from the limestone scarp. Nonetheless, there is some evidence of progressive eastward and southeastward stripping of a protective cover from above the limestone. Limestone outcrops towards the scarp edge are more dissected than those further downdip, suggesting more prolonged exposure. Furthermore, slight bevelling of the limestone outcrop is indicated by the plateau surface dipping at a lower angle than the regional stratigraphic dip of $<1^{\circ}$ to the southeast (Watts et al., 2000); such bevelling is characteristic of dissolutional 'corrosion plains', being very evident on more steeply dipping limestones in the Mendip Hills (Figure 4) and elsewhere.

It has been suggested that the Cotswold scarp and plateau surfaces attained their present relief entirely within the last $450 \mathrm{ka}$, through isostatic uplift in response to excavation of the clay vales immediately to the west (Watts et al., 2000), but the basic premise on which this thesis was based is questionable (Simms, 2001). Pleistocene uplift may be one component in the development of the landscape in this region, but protection of the limestone from dissolution, until relatively recently, by an insoluble cover rock must have been a more significant factor.

But there are some limestone uplands for which no clear explanation can be found other than relatively recent uplift. The Chalk uplands of the Yorkshire and Lincolnshire Wolds lack any obvious siliciclastic cover which might have protected them from dissolutional lowering, other than extensive spreads of glacial till. Their present relief implies that there may have been significant Pleistocene uplift in this area, a possibility already suggested for some of the chalklands further south (Jones, 1999). Clearly more work needs to be undertaken in these seemingly anomalous areas. 


\section{CONCLUSIONS}

There are fundamental differences between the processes involved in denudation of limestone and of silicates. Limestone is removed primarily by dissolution, which operates at all flow velocities across the entire outcrop, while silicates are removed mainly by erosion, which operates only above a minimum threshold velocity and hence is confined largely to watercourses. A consequence of this is that factors that inhibit one process may actually accentuate the other. In particular, abundant vegetation and non-seasonal precipitation inhibit silicate erosion but accentuate carbonate dissolution, while sparse vegetation and sporadic or highly seasonal rainfall favour erosion over dissolution. Consequently denudation of mixed lithology outcrop patterns differs widely under these contrasting climatic regimes. Erosion predominates in the former while dissolution is prevalent in the latter, producing topographies that are virtually the inverse of each other. Differential denudation rates between limestone and silicates may also produce a topographic inversion over time, a crucial factor to be considered in any interpretation of landscape or drainage evolution.

In the temperate humid climate that has prevailed across Britain and Ireland through much of the Tertiary, limestone outcrops should form significantly lower relief areas than adjacent silicates. This is certainly true across much of Ireland where the Carboniferous Limestone outcrop rarely rises above $60 \mathrm{~m}$ OD and forms an extensive central plain. The presence of upland limestone areas in Ireland and in Britain would seem anomalous but most owe much of their present relief to relatively recent removal of a clastic cover which protected the limestone beneath from dissolutional surface lowering. Pleistocene glaciations have been particularly significant in this respect, being more effective than fluvial erosion at large-scale removal of weathered silicate residues.

Preferential removal of limestone by dissolution from across extensive outcrops may cause isostatic uplift at a rate more rapid than the denudation of silicate outcrops, accentuating the relief between limestone and silicate outcrops. The present relief of the southern half of Ireland, in which upland areas are developed almost exclusively on silicate outcrops, may owe much to this mechanism.

The main conclusion to arise from this comparison of weathering and erosion styles is that denudation of limestone and of silicates cannot be encompassed by simple models of differential mechanical erosion of hard and soft rocks. The mechanisms involved, and the factors which influence them, are so fundamentally different that the denudation of these two main lithologies must be considered separately before the results are combined in any overview of the evolution of a mixed-lithology landscape.

\section{ACKNOWLEDGEMENTS}

I thank Sarah Taylor and Adrian Phillips for helpful discussion on the role of isostasy in the Irish landscape.

\section{REFERENCES}

Ahnert F. 1970. Functional relationships between denudation, relief and uplift in large mid-latitude drainage basins. American Journal of Science 268: 243-263.

Allen PA, Bennett SD, Cunningham MJM, Carter A, Gallagher K, Lazzaretti E, Galewsky J, Densmore AL, Phillips WEA, Naylor D, Hach C. 2002. The post-Variscan thermal and denudational history of Ireland. In Exhumation of the North Atlantic Margin: Timing, Mechanisms and Implications for Petroleum Exploration, Doré A, Cartwright J, Stoker M, Turner J, White N (eds). Special Publication, 196. Geological Society: London; 371-399.

Arkell WJ. 1933. The Jurassic System in Great Britain. Clarendon Press: Oxford.

Atkinson TC, Smith DI. 1976. The erosion of limestones. In The Science of Speleology, Ford TD, Cullingford CHD (eds). Academic Press: London; 151-177.

Ballantyne CK, Harris C. 1994. The Periglaciation of Great Britain. Cambridge University Press: Cambridge.

Boggs S. 1987. Principles of Sedimentology and Stratigraphy. Macmillan: New York.

Bouchard M, Jolicoeur S. 2000. Chemical weathering studies in relation to geomorphological research in southeastern Canada. Geomorphology 32: $213-238$.

Brandt CJ, Thornes JB. 1987. Erosional energetics. In Energetics of Physical Environment, Gregory KJ (ed.). Wiley: Chichester; $51-87$. Bridgland DR. 1994. Quaternary of the Thames. Geological Conservation Review, 7. Chapman \& Hall: London.

Carson MA, Kirkby MJ. 1972. Hillslope Form and Process. Cambridge Geographical Studies No. 3. Cambridge University Press: Cambridge.

Clayton K, Shamoon N. 1998. A new approach to the relief of Great Britain. II. A classification of rocks based on relative resistance to denudation. Geomorphology 25: 155-171.

Clayton K, Shamoon N. 1999. A new approach to the relief of Great Britain. III. Derivation of the contribution of neotectonic movements and exceptional regional denudation to the present relief. Geomorphology 27: 173-189. 
Coxon P. 2001a. Cenozoic: Tertiary and Quaternary (until 10000 years before present). In The Geology of Ireland, Holland CH (ed.). Dunedin Acadmic Press: Edinburgh; 387-427.

Coxon P. 2001b. Understanding Irish landscape evolution: pollen assemblages from Neogene and Pleistocene palaeosurfaces in western Ireland. Biology and Environment: Proceedings of the Royal Irish Academy 101B: 85-97.

Craig RG. 1987. Dynamics of a Missoula flood. In Catastrophic Flooding, Mayer L, Nash D (eds). Allen and Unwin: Boston; $305-332$.

Crowther J. 1979. Limestone solution on exposed rock outcrops in west Malaysia. In Geographical Approaches to Fluvial Processes, Pitty AF (ed.). Geoabstracts: Norwich; 31-50.

Douglas I. 1967. Man, vegetation, and the sediment yield of rivers. Nature 215: 925-928

Drew DP. 2001. Classic Landforms of the Burren Karst. The Geographical Association.

Eaton LS, Morgan BJ, Kochel RC, Howard AD. 2003. Role of debris flows in long-term landscape denudation in the central Appalachians of Virginia. Geology 31: 339-342.

Emmett WW. 1978. Overland flow. In Hillslope Hydrology, Kirkby MJ (ed.). Wiley: Chichester; 145-170.

Farrant AR, Smart PL. 1997. The geomorphic evolution of the Mendip Hills. Proceedings of the Bristol Naturalists' Society 55: $135-158$.

Farrant AR, Smart PL, Whitaker FF, Tarling DH. 1995. Long-term Quaternary uplift rates inferred from limestone caves in Sarawak, Malaysia. Geology 23: 357-360.

Ford DC. 1980. Threshold and limit effects in karst geomorphology. In Thresholds in Geomorphology, Coates DR, Vitek JD (eds). George Allen \& Unwin; 345-362.

Ford DC, Drake JJ. 1982. Spatial and temporal variations in karst solution rates: the structure of variability. In Space and Time in Geomorphology, Thorn CE (ed.). Allen \& Unwin: London; 147-170.

Ford DC, Williams PW. 1989. Karst Geomorphology and Hydrology. Unwin Hyman: London.

Gilchrist AR, Summerfield MA, Cockburn HAP. 1994. Landscape dissection, isostatic uplift, and the morphologic development of orogens. Geology 22: 963-966.

Golubev GN. 1982. Soil erosion and agriculture in the world: an assessment and hydrological implications. In Recent Developments in the Explanation and Prediction of Erosion and Sediment Yield, Walling DE (ed.). Publication no. 137. International Association of Hydrological Sciences: Wallingford; 261-268.

Goudie AS. 1989. Weathering processes. In Arid Zone Geomorphology, Thomas DSG (ed.). Belhaven: London; 11-24.

Goudie AS. 1990. The Landforms of England and Wales. Blackwell: Oxford.

Gunn J. 1986. Solute processes and karst landforms. In Solute Processes, Trudgill ST (ed.). Wiley: Chichester; 363-437.

Hack JT. 1960. Interpretation of erosional topography in humid temperate regions. American Journal of Science 258-A: 80-97.

Herries Davies GL, Stephens N. 1978. The Geomorphology of the British Isles: Ireland. Methuen and Co.: London.

Hjulström F. 1935. Studies of the morphological activity of rivers as illustrated by the river Fyris. Bulletin of the Geological Institute of the University of Uppsala 25: 221-527.

Jennings JN. 1967. Some karst areas of Australia. In Landform Studies from Australia and New Guinea, Jennings JN, Mabbutt JA (eds). A.N.U. Press: Canberra; 256-292.

Jennings JN. 1985. Karst Geomorphology. Blackwell: Oxford.

Jones DKC. 1981. The Geomorphology of the British Isles: Southeast and Southern England. Methuen and Co.: London.

Jones DKC. 1999. Evolving models of the Tertiary evolutionary geomorphology of southern England, with special reference to the Chalklands In Uplift, Erosion and Stability: perspectives on long-term landscape development, Smith BJ, Whalley WB, Warke PA (eds). Special Publication, 162. Geological Society: London; 1-23.

Knighton AD. 1973. Riverbank erosion in relation to streamflow conditions, River Bollin-Dean, Cheshire. East Midland Geographer 5: 416426.

Lang S. 1977. Relationship between world-wide karstic denudation (corrosion) and precipitation. Proceedings of the 7th International Speleological Congress, Sheffield. British Cave Research Association: Bridgewater; 282.

Langbein WB, Schumm SA. 1958. Yield of sediment in relation to mean annual precipitation. Transactions of the American Geophysicists Union 39: 1076-1084.

Lauritzen S-E, Lundberg J. 2000. Meso- and micromorphology of caves: Solutional and erosional morphology. In Speleogenesis: Evolution of Karst Aquifers, Klimahouk AB, Ford DC, Palmer AN, Dreybrodt W (eds). National Speleological Society; 408-426.

Leake BE, Tanner PWG. 1994. The Geology of the Dalradian and Associated Rocks of Connemara, Western Ireland. Royal Irish Academy: Dublin.

Leopold LB, Wolman MG, Miller JP. 1964. Fluvial Processes in Geomorphology. Freeman: San Fransisco.

Meyer GA, Wells SG, Balling RC, Jull AJT. 1992. Response of alluvial systems to fire and climate change in Yellowstone National Park. Nature 357: 147-150.

Montgomery DR. 1994. Valley incision and the uplift of mountain peaks. Journal of Geophysical Research 99B: 13913-13921.

Moody JA, Martin DA. 2001. Initial hydrologic and geomorphic response following a wildfire in the Colorado Front Range. Earth Surface Processes and Landforms 26: 1049-1070.

Morisawa M. 1985. Rivers. Longman Geomorphology Texts 7. Longman: London.

Naylor D. 1998. Irish shorelines through geological time. Occasional Papers in Irish Science and Technology, 17. Royal Dublin Society.

Novak ID. 1973. Predicting coarse sediment transport: The Hjulström Curve revisited. In Fluvial Geomorphology, Morisawa M (ed.). Allen \& Unwin: London; 13-25.

Oberlander TM. 1989. Slope and pediment systems. In Arid Zone Geomorphology, Thomas DSG (ed.). Belhaven: London; 58-59.

Oguchi CT, Hatta T, Matsukura Y. 1999. Weathering rates over 40000 years based on changes in rock properties of porous rhyolite. Physics and Chemistry of the Earth (A) 24: 861-870.

Ohmori H. 1983. Erosion rates and their relation to vegetation from the viewpoint of world-wide distribution. Bulletin of the Department of Geography, University of Tokyo 15: 77-91.

Pazzaglia FJ, Gardiner TW. 1994. Late Cenozoic flexural deformation of the middle U.S. Atlantic passive margin. Journal of Geophysical Research 99: 12143-12157.

Phillips JD. 2002. Erosion, isostatic response, and the missing peneplains. Geomorphology 45: 225-241. 
Phillips WEA. 2001. The pre-Quaternary evolution of the Irish landscape. Occasional Papers in Irish Science and Technology; 23.

Pitty AF. 1968. The scale and significance of solutional loss from the limestone tract of the southern Pennines. Proceedings of the Geologists' Association 79: 153-177.

Schmidt, K-H. 1985. Regional variation of mechanical and chemical denudation, Upper Colorado River basin, U.S.A. Earth Surface Processes and Landforms 10: 497-508.

Scoging, H. 1989. Runoff generation and sediment mobilisation by water. In Arid Zone Geomorphology, Thomas DSG (ed.). Belhaven: London; 87-116.

Sevastopulo GD, Wyse Jackson PN. 2001. Carboniferous (Dinantian). In The Geology of Ireland. Holland CH (ed.). Dunedin Academic Press: Edinburgh; 241-288.

Shennan I. 1989. Holocene crustal movements and sea-level changes in Great Britain. Journal of Quaternary Science 4: 77-89.

Simms MJ. 1997. The geological history of the Mendip Hills and their margins. Proceedings of the Bristol Naturalists' Society 55: 113134.

Simms MJ. 2001. Discussion on lithospheric flexure, uplift, and landscape evolution in south-central England. Journal of the Geological Society of London 158: 877.

Simms MJ, Boulter MC. 2000. Oligocene cave sediments in Co. Cork: implications for reconstructing the Tertiary landscape of southwest Ireland. Proceedings of the Geologists' Association 111: 363-372.

Small EE, Anderson RS. 1995. Geomorphologically driven Late Cenozoic rock uplift in the Sierra Nevada, California. Science 270: 277280.

Smart PL, Waltham AC, Yang M, Zhang Y-J. 1986. Karst geomorphology of western Ghizhou, China. Cave Science 13: 89-103.

Smith DG. 1973. Aggradation of the Alexandra-North Saskatchewan River, Banff Park, Alberta. In Fluvial Geomorphology, Morisawa M (ed.). Allen and Unwin: London; 201-219.

Stark CP, Stark GJ. 2001. A channelization model of landscape evolution. American Journal of Science 301: 486-512.

Summerfield MA. 1991. Global Geomorphology. Longman: London.

Sundborg A. 1956. The river Klarälven, a study of fluvial processes. Geografiska Annaler 38: 127-316.

Sweeting MM. 1974. Karst geomorphology in north-west England. In The Limestones and Caves of North-west England, Waltham AC (ed.). David \& Charles: Newton Abbot; 46-78.

Sweeting MM. 1990. The Guilin karst. Zeitschrift für Geomorphologie, N.F, Suppl.-Bd. 77: 47-65.

Trudgill ST. 1976. The subaerial and subsoil erosion of limestones on Aldabra Atoll, Indian Ocean. Zeitschrift für Geomorphologie, Supplement Band 26: 201-210.

Trudgill ST. 1977. The role of a soil cover in limestone weathering. Cockpit Country, Jamaica. Proceedings of the 7th International Speleological Congress, Sheffield. British Care Research Association: Bridgewater; 401-404.

Trudgill ST, Pickles AM, Smettem KRJ, Crabtree RW. 1983. Soil water residence time and solute uptake. 1: Dye tracing and rainfall events. Journal of Hydrology 60: 257-279.

Viles HA, Trudgill ST. 1984. Long term measurements of micro-erosion meter sites, Aldabra Atoll, Indian Ocean. Earth Surface Processes and Landforms 9: 89-94.

Walling DE, Webb BW. 1986. Solutes in river systems. In Solute Processes, Trudgill ST (ed.). Wiley: Chichester; 251-327.

Waltham AC, Simms MJ, Farrant AR, Goldie H. 1997. The Karst and Caves of Great Britain. Geological Conservation Review Series. Chapmanand Hall: London.

Watts AB, McKerrow WS, Fielding E. 2000. Lithospheric flexure, uplift, and landscape evolution in southcentral England. Journal of the Geological Society of London 157: 1169-1177.

White WB. 1988. Geomorphology and Hydrology of Karst Terrains. Oxford University Press: Oxford.

Williams PW. 1970. Limestone morphology in Ireland. In Irish Geographical Studies, Glasscock R, Stephens N (eds). Queen's University Press: Belfast; 105-124.

Williams PW. 1978. Interpretations of Australasian karsts. In Landform Evolution in Australasia, Davies JL, Williams MAJ (eds). A.N.U. Press: Canberra; 259-286.

Williams RBG. 1980. The weathering and erosion of chalk under periglacial conditions. In The Shaping of Southern England, Jones DKC (ed.). Academic Press: London; 225-248.

Wilson L. 1973. Variations in mean annual sediment yield as a function of mean annual precipitation. American Journal of Science 273: $335-349$.

Wolman MG, Miller J. 1960. Magnitude and frequency of forces in geomorphic processes. Journal of Geology 68: 54-74. 